\title{
An Evaluation of the 1997 \\ JPL Summer Teacher Enhancement Program
}

Jet Propulsion Laboratory

Teaching Resource Center

October 20, 1997

\author{
by \\ Simeon P. Slovacek, Ph.D. \\ and \\ Adelaide R. Doyle-Nichols, Ph.D.
}




\section{DISCLAIMER}

This report was prepared as an account of work sponsored by an agency of the United States Government. Neither the United States Government nor any agency thereof, nor any of their employees, makes any werranty, express or implied, or assumes any legal liability or responsibility for the securacy, completeness, or usefulness of any information, apparatus, product, or process disclosed, or represents that its use would not infringe privately owned rights. Reference herein to any specific commercial product, process, or service by trade name, trademark, manufacturer, or otherwise does not necessarily constitute or imply its endorsement, recommendation, or favoring by the United States Government or any agency thereof. The views and opinions of authors expressed herein do not necessarily state or reflect those of the United States Governmeat or any agency thereof. 


\section{DISCLAIMER}

Portions of this document may be illegible in electronic image products. Images are produced from the best available original document. 


\section{Table of Contents}

Executive Summary _ 1

Summary of Recommendations ___ 2

Introduction _ـ 3

Participant Background Information___ 4

Evaluation Findings____ 8

Appendices__ 19

Appendix A - 1997 JPL Summer Teacher Enhancement Program Schedules

Appendix B - Questionnaires: "Pre Program" and "End of Program"

Appendix C - Written Responses: Open Ended Question Answers and Comments 


\section{Executive Summary}

- 18 middle school science teachers participated in a four week summer institute where they learned about earth and space science, Internet/WWW, and more effective science teaching methods.

- The participating teachers from target inner city, predominantly minority public middle schools. There were 10 males $(55.6 \%)$ and 8 females $(44.4 \%)$ who participated. $51 \%$ were minorities.

- Over 15 Scientists, Engineers, Technical JPL Staff, and 4 University professors from Cal State LA, and 1 speaker from the LA County Office of Education served in some other capacity in the project. Most served as lecturers, workshop leaders, scientists, lab facilitators and tour guides who shared their work.

- Overall, the Summer Teacher Enhancement Program was highly successful according to the participating teachers. $\mathbf{8 8 . 2 \%}$ would "definitely" recommend and $\mathbf{1 1 . 8 \%}$ would "maybe" recommend the program to other teachers. 58.8\% rated the program "The Best" (35.2\%) or "Much Better than others" (23.5\%). Only 2 participants out of 17 felt it was "Average".

- Typical student comments were "The science speakers were invaluable!" and "We were exposed to a terrific range of technologies. I feel much more confident taking technology back to my classroom!"

- The highest rated activities/lecture were the "Mars \& Pathfinder", the "Model Rocket Building and Launching at CSLA", and the "Journals and Webs".

- The lowest rated activity was the workshop on Educational Assessment where 53\% rated it as "fair" or "poor" although 2 participants or 12\% rated it as "excellent".

- $9(53 \%)$ of the participants felt the program was too broad (covering too many topics) and that there should be more closure on each topic, while $8(47 \%)$ felt the coverage was about right.

- Statistically, if one were to generalize the results of the program, the growth in the teachers' confidence levels improved significantly $(p<=1)$ in the areas of "knowledge level" (about science and teaching), "telecommunications" (Internet/WWW), and "computers".

- Thus far, over 8 days of follow-up activities have been scheduled for the participants between September, 1997 to May 1998. 


\section{Summary of Recommendations}

(These recommendations are made should the program be refunded next year.)

- Participant response to most of the workshops and activities was quite positive, so next year's program requires little change of curriculum. Sessions that were rated as "average" or below included "unit of practice", "multiple intelligences", "science framework", and "educational assessment" and could use some fine-tuning.

- To improve next year's program consider the following steps:

- focus on refining the above sessions

- cover fewer topics and reaching greater closure on the topics covered. (Some students felt they were assigned extensive readings, e.g. science standards, that were not later covered in much detail.)

- model the teaching behaviors expected (i.e. more hands-on and less lecturing)

- consolidate the "technology project" and "unit of practice"

- For the "unit of practice", the following is recommended:

- develop clearer guidelines and release them earlier in the program

- provide students with appropriate models or examples to clarify what is expected

- consider using a few former STEP teachers from prior years who would model or demonstrate their best lessons as part of the STEP program.

- The incentives such as the stipend, credit units and enticing course content should be maintained as they seem quite effective.

- The requirements for computer access, EMAIl accounts and WWW access (though AOL, Earthlink, and other ISP's) served the project well this year, and should be continued as there was much more electronic networking than in prior years.

- Consider increasing the informal contact participating teachers have with JPL scientists and engineers.

- Consider inviting one or more of the previous year's STEP mini-grant recipients to present the results of their mini-grant projects to the current STEP participants.

- Consider scheduling, on a volunteer basis, some of the follow-up activities at the participants' schools so that there can be continued sharing and some "show and tell".

- Seek additional funding to offer the program again next year.

- Consider publishing the results in a professional journal and presenting the results of the STEP program at professional association meetings. 


\section{Introduction}

\section{Program Components}

There were two major program components in the Jet Propulsion Laboratory (JPL) Summer Teacher Enhancement Program (STEP). First, the Summer Institute was structured as a four week 4 credit unit University course and consisted of workshops, lectures, labs and tours as activities. The second component consists of follow-up activities related to the summer institute's contents and again is structured as a University credit bearing course for participants to reinforce their summer training. An additional list of at least 8 days worth of follow-up activities was developed to be scheduled from September 1997 through May 1998. Since only one of the follow-up activities have taken place as of this writing, they are not addressed in this report other than to mention planned activities. The effectiveness of the follow-up activities will be presented in a supplemental follow-up evaluation report along with the evaluator's observations of a sampling of the participants classrooms teaching practices, and a four year retrospective of the STEP programs.

\section{1) Summer Workshop Activities:}

Appendix A provides a copy of the "1997 Summer Teacher Enhancement Program (STEP) Program" schedule which gives an overview of the program activities. These included - JPL tours, workshops, lectures on a variety of space science topics including comets, various JPL planet exploration projects, environmental (global) science, activities on science journals, Internet, multiple intelligence's, model rocket building and launching at Cal State LA, Challenger Center visit, a Mt. Wilson Observatory visit, educational and authentic assessment, HyperStudio, grant writing, science software (including JPL and NASA developed CD-ROMs), and two class projects - one in technology and one as a unit of practice for teachers to develop for use with their science classes. INTERNET presentations and lab activities included NASA Spacelink, EMAIL, Netscape, World Wide Web, and other network and telecommunication resources.

Staff: Project staff consisted of the project director and principal investigator (for project management), a co-project director who is a faculty member at Cal State LA, a full time master teacher (lead trainer and follow-up activities coordinator), support staff, JPL scientists, engineers, and staff who served as lecturers, workshop leaders, tour guides, and mentors, and four Cal State LA faculty members. About fifteen JPL staff were involved in this program.

Dates: The actual training dates of the main workshop took place from July 7.1997 to August 5, 1997 - four and a half weeks. The program weeks were each about 30 scheduled hours long with a two day recess during the third week. 
Sites: The training sites included the JPL Education Resource Center, Cal State LA, the Jet Propulsion Lab, the Challenger Center at CSU Dominguez Hills, and Mt. Wilson Observatory.

Incentives: Participating teachers were paid a stipend of about $\$ 1,400$ with the expectation that they would attend all of the sessions. Both the Summer Institute (STEP program) and the follow-up activities were created as two separate college courses so that completing the Summer Institute resulted in participating teachers being awarded up to 4 units of graduate credit (two units paid for by the project and two optional units paid by the participating teachers). Participating teachers completing the follow-up activities will be awarded an additional credit unit for the second follow-up course. Also, participants were encouraged to write mini-grants to fund projects at their schools.

The workshops on grant writing culminated in participating teachers writing mini proposals which were reviewed and funded on a competitive basis out of the JPL/NASA grant. A fund of about $\$ 12,000$ was made available for this purpose. This provided a number of the participating teachers with resources to implement more hands-on curriculum in their science courses or provide staff development at their schools. Finally, the content of the program promises science teachers will learn many of the tools they need to improve their teaching (e.g. space and earth science curriculum, technology etc.)

\section{2) Follow-up Activities:}

A draft follow-up schedule was developed distributed via EMAIL at the end of summer session by the Master Teacher/Trainer. Detailed follow-up activities are still being arranged for the participants. About 8 days (sessions) of activities are being planned. Participants were surveyed at the end of the course to indicate their preferences for different topics. The length of the time allotted for each depends on the activity but is typically a minimum of 3 hours to a maximum of a full day. In order to insure a minimal level of participation in follow-up activities - the program was structured to require a fixed levels of attendance of follow-up activities by each of the participants in order for them to earn the University credit unit. (They receive 1 credit unit for the follow-up activities).

\section{Participant Background Information}

Who were the project participants? 21 teachers were accepted into the program, 19 actually started, and there were 18 participant teachers who completed the four and a half week workshop. All of the teachers were from the greater Los Angeles Metropolitan area and commuted to the sessions each day. The gender mix of the teachers was 10 males and 8 females as indicated in Chart 1 . below. 


\section{Chart 1.}

\section{Gender}

1997 JPL/STEP Institute

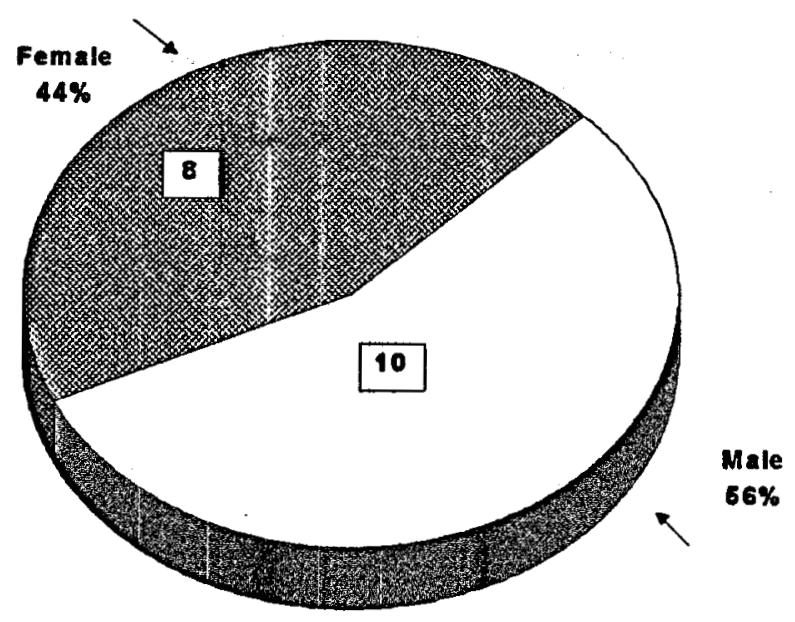

The group was somewhat ethnically diverse and estimated visually by the evaluator as mainly Caucasian participants (9) followed by Blacks (5), Hispanics (3), and one (1) Asian. No self-reported ethnic data was collected on the ethnicity of the participating teachers. The students of these middle school teachers, however, were mainly (over 85\%) Black and Hispanic. Chart 2. below indicates the estimated ethnic distribution of the participants.

Chart 2.

Ethnicity

1997 JPL/STEP Institute

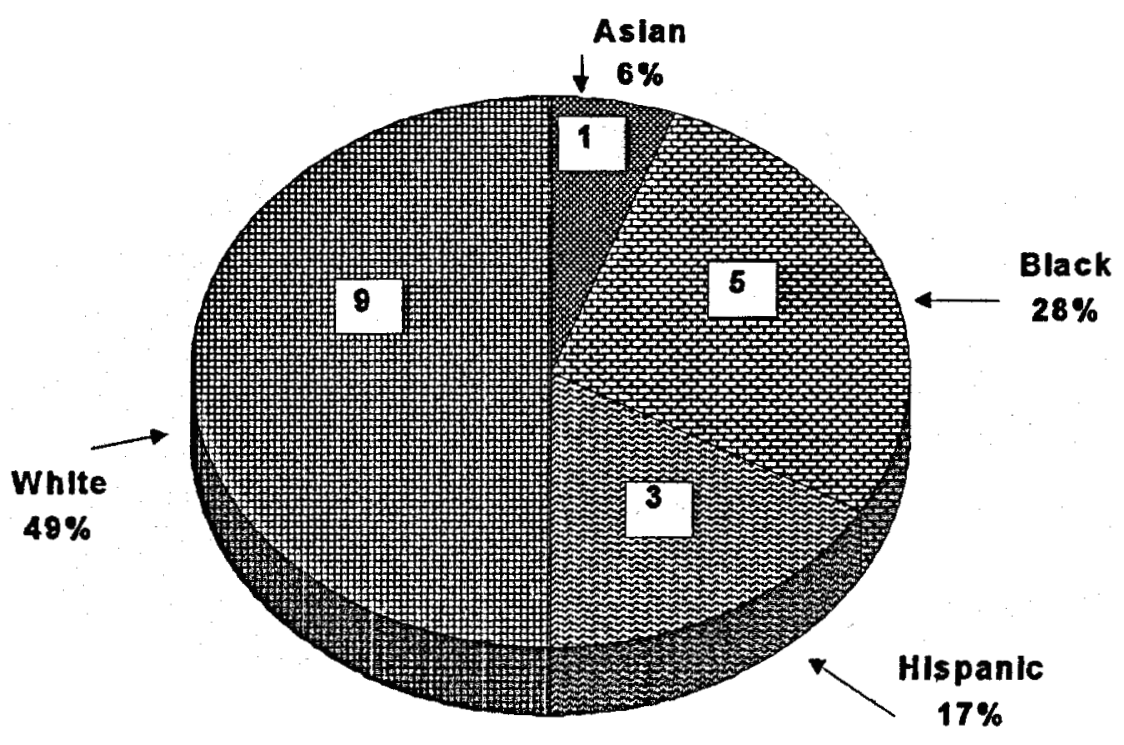


All of the teachers taught middle school grades (6th through 8th grades). The years of experience teaching science by the participating teachers are indicated in the pie chart below (Chart 3.). Over half (53\%) of the participating teachers had 6 or more years experience in teaching science education. While $47 \%$ were fairly new science teachers having 5 years or less experience. Four teachers were first year teachers.

\section{Chart 3. \\ Years Experience Teaching Science \\ 1997 JPL/STEP Institute}

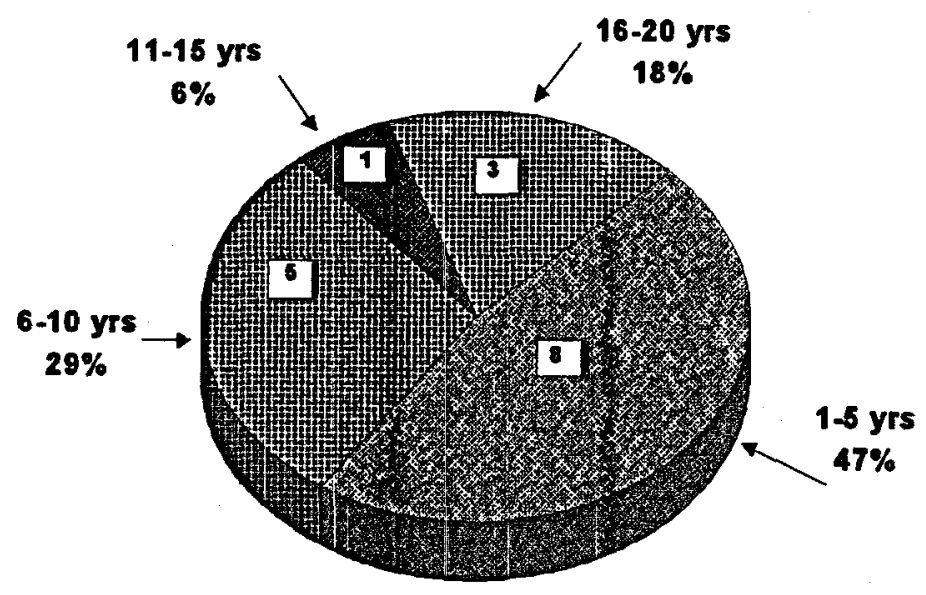

The years of experience teaching math by the participating teachers are indicated in the pie chart below (Chart 4.). 11 of the participating teachers had some mathematics teaching experiences although $6(35 \%)$ did not.

\section{Chart 4.}

\section{Years Experience Teaching Math}

1997 JPL/STEP Institute

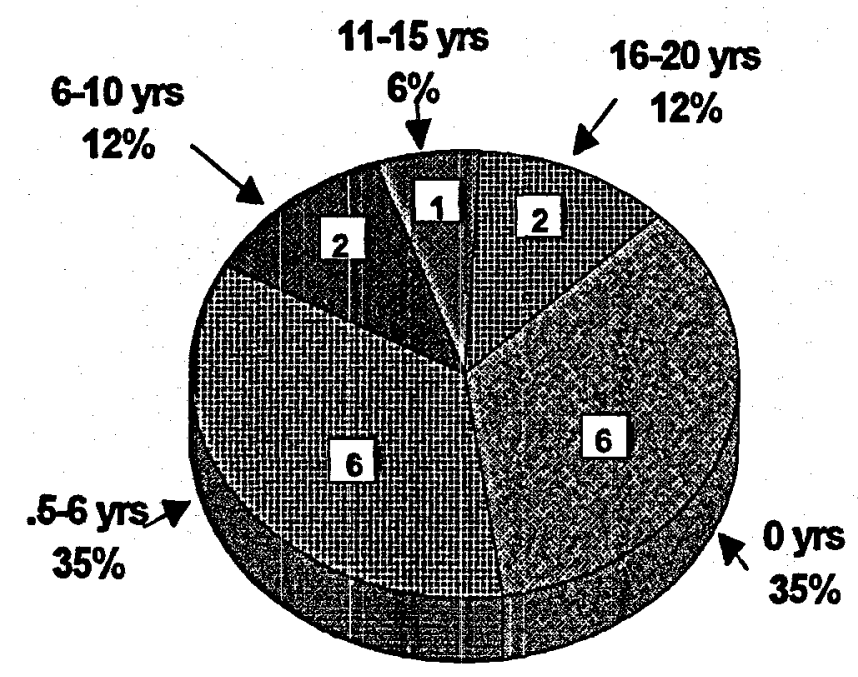


Concerning the degrees held by the participants, Chart 5 , below shows that $8(47 \%)$ held bachelors degrees in science. The majority held degrees in fields other than science. No one held a degree in math.

\section{Chart 5.}

\section{Bachelors Degree Subject}

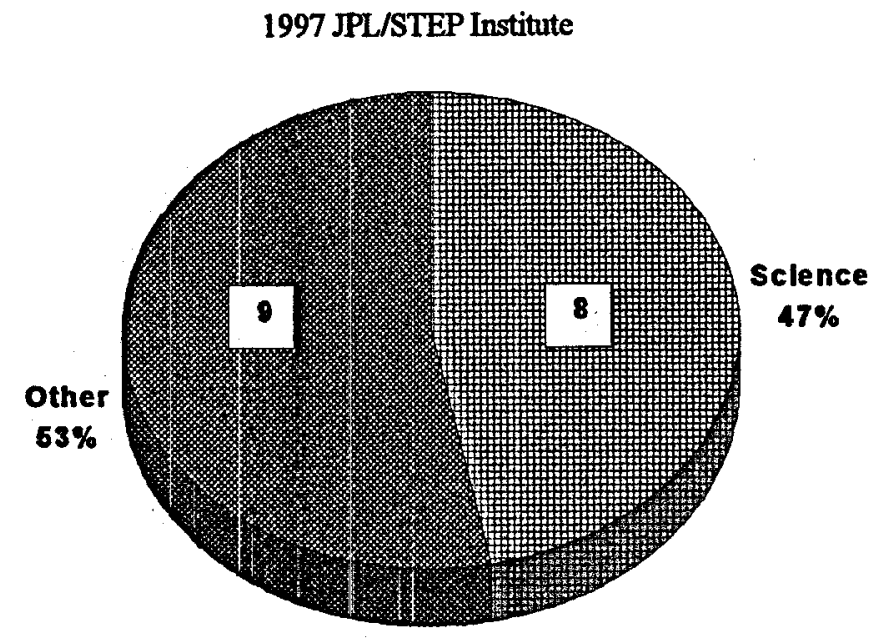

Concerning the masters degrees held by the participants, Chart 6 , below shows that 5 (29.4\%) held masters degrees in education. Most 12 (or 70.6\%) of the participants did not have a masters degree.

\section{Chart 6.}

\section{Masters Degree Subject}

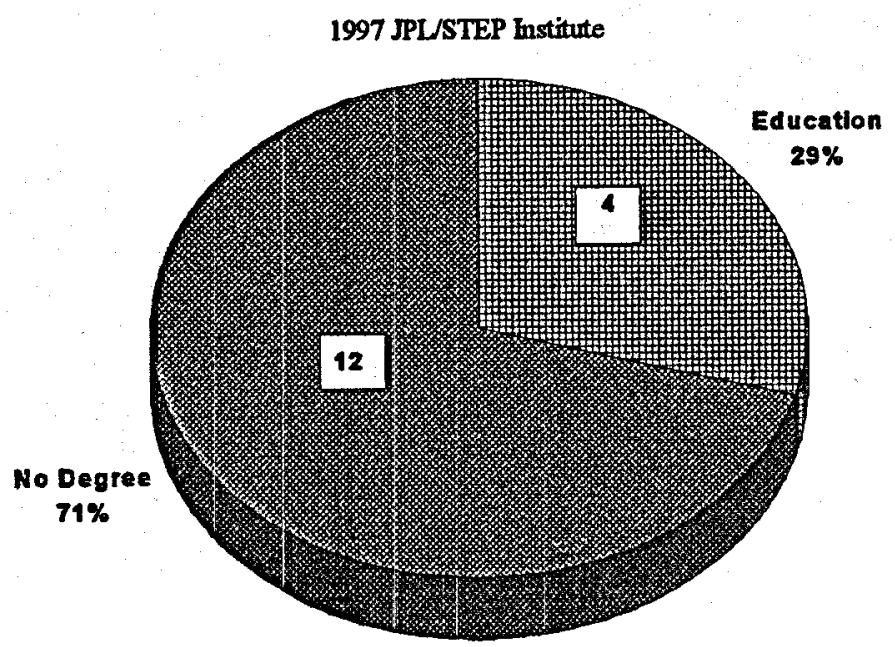




\section{Evaluation Findings}

Instrumentation: Appendix B contains copies of the formal evaluation instruments. These two instruments consisted of a pre-program and an end-of-summer program questionnaire, and were created by the evaluator. The evaluation instruments were 1) $J P L$ Summer Teacher Enhancement Program Pre Program Questionnaire (1997-78) and 2) JPL Summer Teacher Enhancement Program End of Summer Program Questionnaire (1997). The "Pre Program" survey was used to gather participant background, attitudinal, and teaching practice information prior to the workshop, and the "End of Program" survey was used to gather much of the same attitudinal and teaching practice data to measure change. Also, it was expanded by the evaluator to ask some questions about the participant perceptions on the JPL workshops and their effectiveness. This report analyzes those surveys, particularly to establish pre and post changes in attitudes toward, confidence levels and strategies in teaching science.

Appendix C contains written comments from the "End of Program" survey. All student responses to the open-ended questions are recorded verbatim in Appendix $\mathbf{C}$.

The evaluator observed a sample of 12 (nearly half) sessions and informally interviewed a number of the participants. Notes from those classroom observations and interviews were kept and referred to in this report. The conclusions, findings, and recommendations below and at the beginning of this report are drawn from these instruments, from the direct observation of a sampling of sessions, and from the informal interviews with and comments of the participants.

Retention: 21 teachers were admitted, 19 started the summer program, and 18 completed it. The one student who dropped out was interviewed by phone. His reasons were as follows, he was Internet and WWW savvy to begin with and expected a more advanced course in technology. He was disappointed in the "slipping" schedule, the beginning technology levels of some other participants, and expected a more challenging course. Also, he had worked for Rockwell International in R\&D and was therefore already familiar with high technology and space science. Finally, the drive to CSLA was too long for him. Nevertheless, because of the course, he has changed his teaching to use "hands-on" active learning instead of science textbooks!.

$17(94 \%)$ of the 18 participants completed the "End of Program" survey upon which the following charts and tables are based.

Overall Program Ratings: The program was rated extremely favorably : $88.2 \%$ (15) would definitely recommend the program to other teachers while the other $11.8 \%$ (2) would "Maybe" recommend the program. Participating teachers were also asked "How does STEP compare with other in-service professional development programs for science/math teachers in which you've participated?" As indicated in Chart 7. below, $\mathbf{5 8 . 8 \%}$ rated the program "The Best" (35.2\%) or "Much Better (than others)" (23.5\%). Only 2 participants out of 17 felt it was "Average". 


\section{Chart 7.}

\section{STEP Compared to other In-Service Programs}

1997 JPL/STEP Institute vs other In-service programs

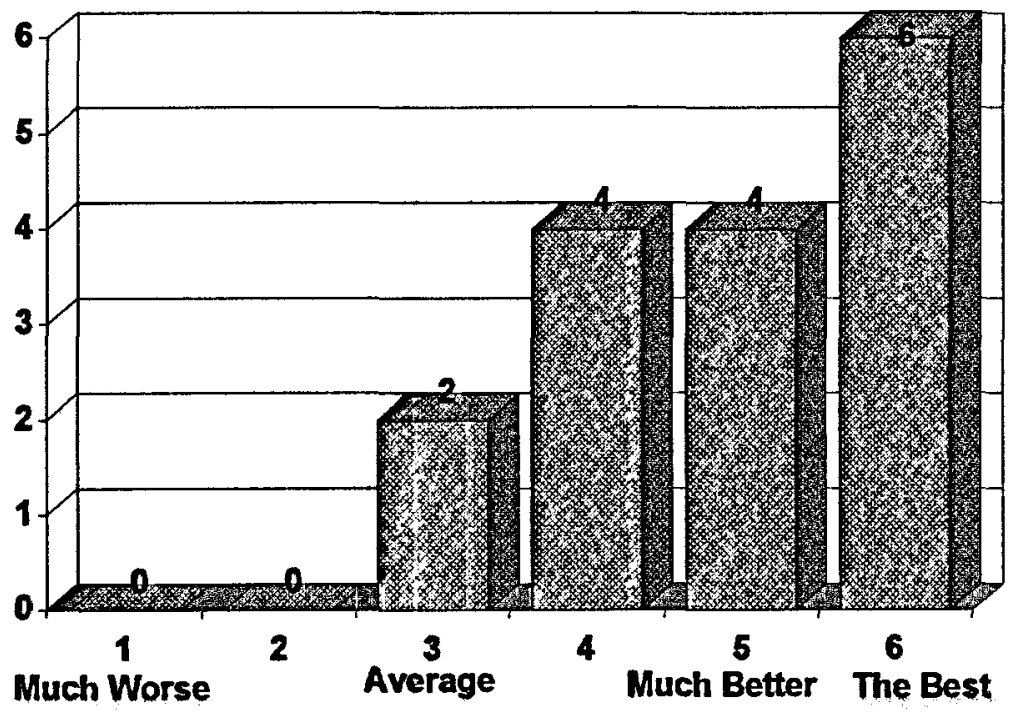

Program Component Ratings:

Participants were then asked to rate specific STEP activities. These included activities like the JPL main lab tours, Cal State LA model rocket launch, the Internet and World Wide Web workshops, the Challenger Center visit, and so on. The rating scale was as follows:

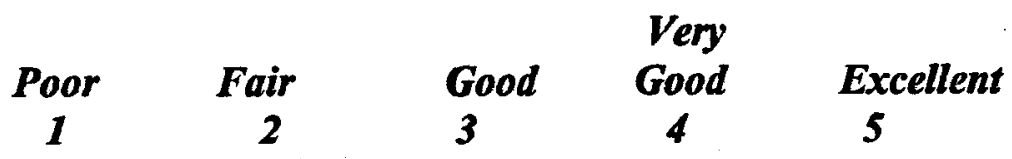

The participating teachers' mean ratings mostly fell between "very good" to "excellent". They may not have liked all of the programs components equally, but overall 17 or $65.3 \%$ of the sessions rated in the STEP program averaged ratings between "very good" and "excellent".

The top rated session was the Mars and Pathfinder Workshop. The Journals and Webs session and the Model Rocker building tied for second highest rated session, followed by the Challenger Center as the third in the ratings. The lowest rated three sessions were the Unit of Practice, Multiple Intelligence's, and Educational Assessment.

Charts 8. and 9. below present the participating teachers' ratings of the various activities. 
Chart 8.

\section{JPL/STEP Program Activity Ratings}

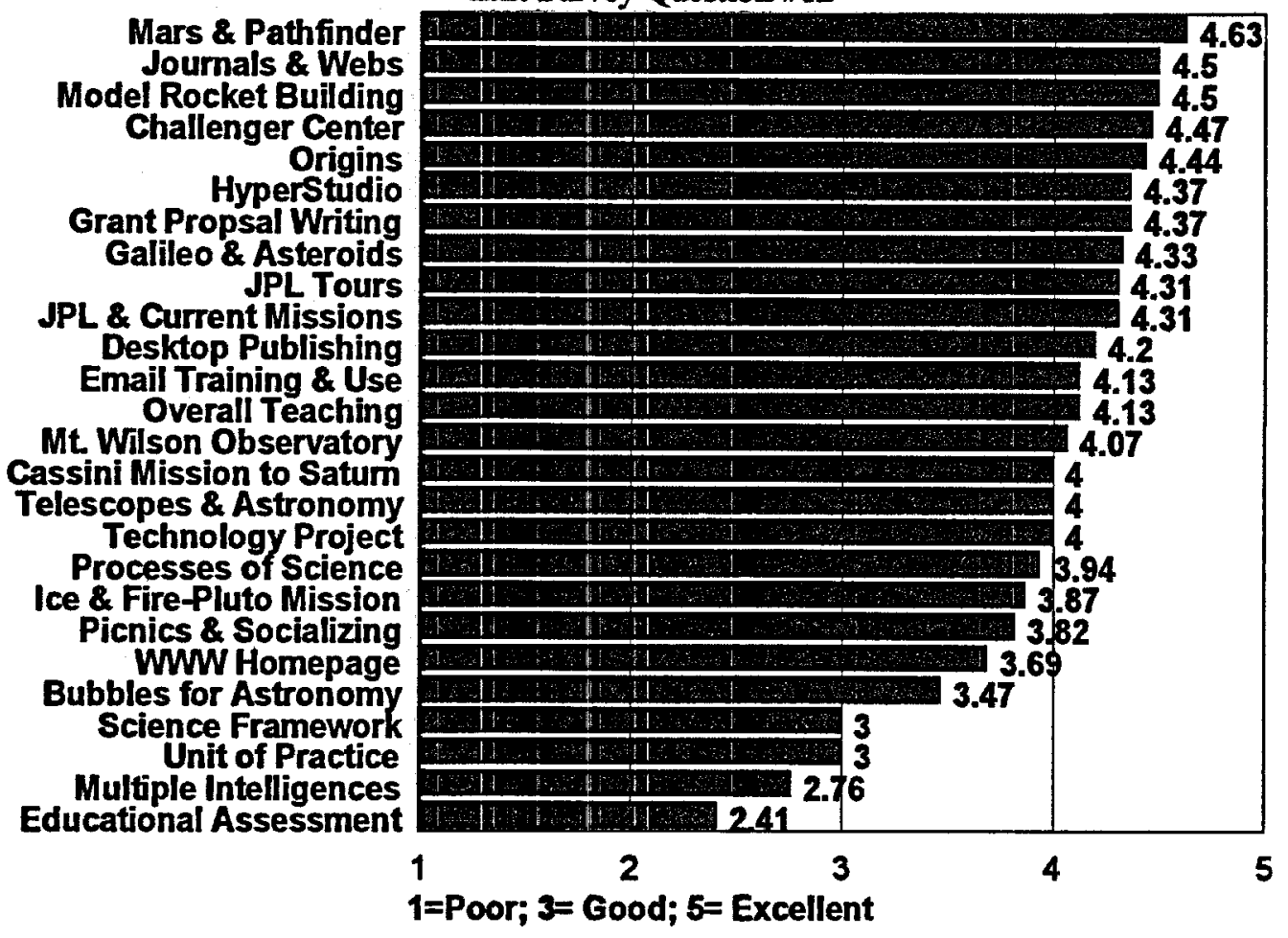

Chart 9.

STEP Program Activity

\begin{tabular}{|c|c|}
\hline & Mean \\
\hline Mars 2 Pathfinder & 4.63 \\
\hline Joumals \& Webs & 4.5 \\
\hline Model Rocket Bullding & 4.5 \\
\hline Challenger Center & 4.47 \\
\hline Origins & 4.44 \\
\hline Hyperstudio & 4.37 \\
\hline Grant Propsal Writing & 4.37 \\
\hline Galleo \& Asterolds & 4.33 \\
\hline JPL Tours & 4.31 \\
\hline JPL \& Curremt Missions & 4.31 \\
\hline Desktop Publishing & 4.2 \\
\hline Emall Training \& Use & 4.13 \\
\hline Overall Teaching & 4.13 \\
\hline Mt. Wilson Observatory & 4.07 \\
\hline Cassinl Mission to Saturn & 4 \\
\hline Tolescopes \& Astronomy & 4 \\
\hline Technology Prolect & 4 \\
\hline Processes of Sclence & 3.94 \\
\hline Ice E Fire Pluto Mission & 3.87 \\
\hline Picnics \& soclallzing & 3.82 \\
\hline Wun Homepage & 8.69 \\
\hline Bubbles for Astronomy & 3.47 \\
\hline Sctence Framework & 3 \\
\hline Unit of Practice & 3 \\
\hline Multiple Intelligences & 2.76 \\
\hline Educational Assessment & 241 \\
\hline
\end{tabular}


Charts 10,11 , and 12 below present the detailed ratings on the two highest and the lowest rated activities in the STEP Program. The top two rated activities were $1^{\text {st }}$ Mars and Pathfinder session, and tied for $2^{\text {nd }}$ were Journals and Webs and Model Rocket Building. The lowest rated activity was "Educational Assessment".

\section{Chart 10.}

\section{Highest Rated Workshop Activity}

Mars and Pathfinder

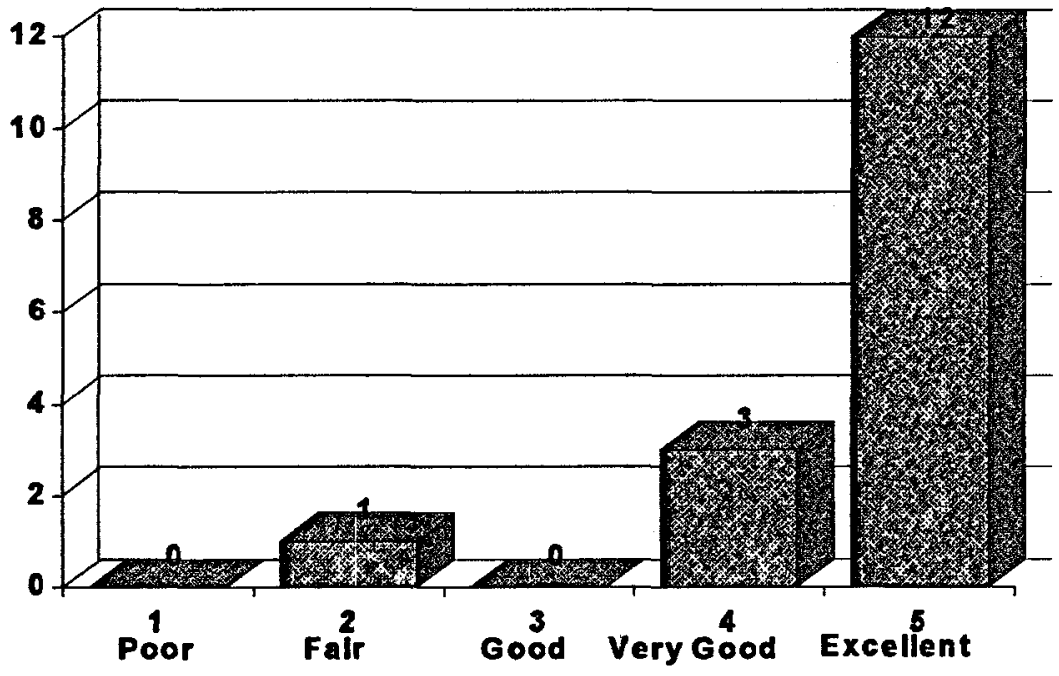

Chart 11.

Second Highest Rated Workshop Activities

Journals and Webs, and Model Rocket Building (tied)

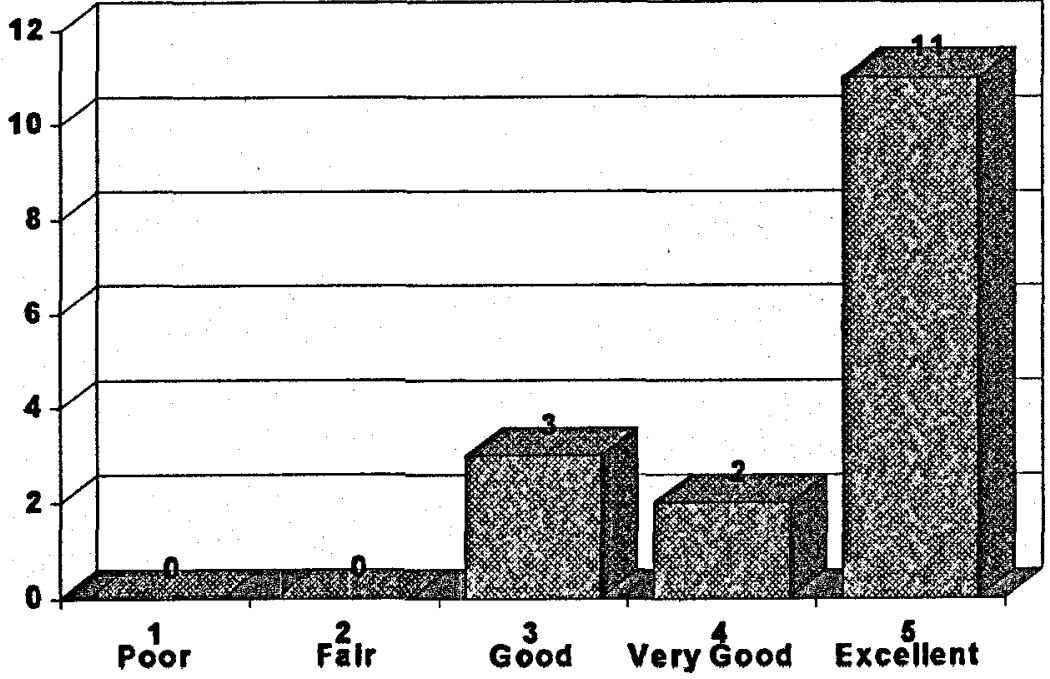




\section{Chart 12.}

\section{Lowest Rated Workshop Activity \\ Educational Assessment}

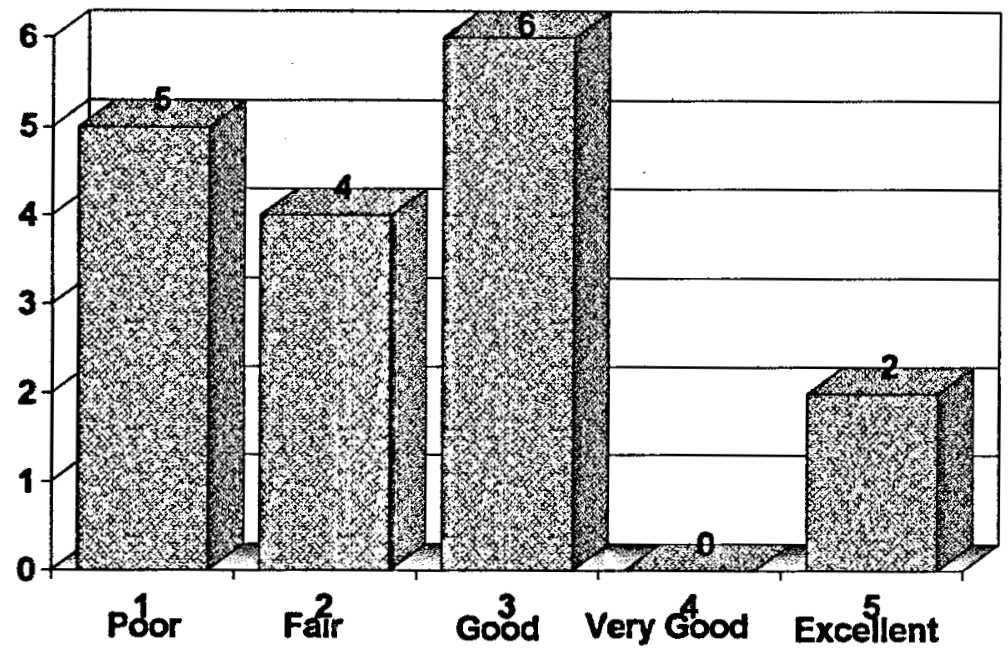

The lowest rated activity was "Educational Assessment" although 2 participants rated it "Excellent". This session should either be eliminated or significantly modified next year if the program is funded again.

Other Question Responses:

From the JPL Summer Teacher Enhancement Program End of Summer Program

Questionnaire 1997 (Appendix B), question 3 asked participants how important is prior computer experience for future STEP participants. Their responses showed that computer experience was quite important with $47 \%$ rating it "Extremely Important" or "Important" and $35 \%$ rating it "Somewhat Important." Chart 13. below presents these results.

\section{Chart 13.}

How Important is Computer Experience? 1997 JPL/STEP

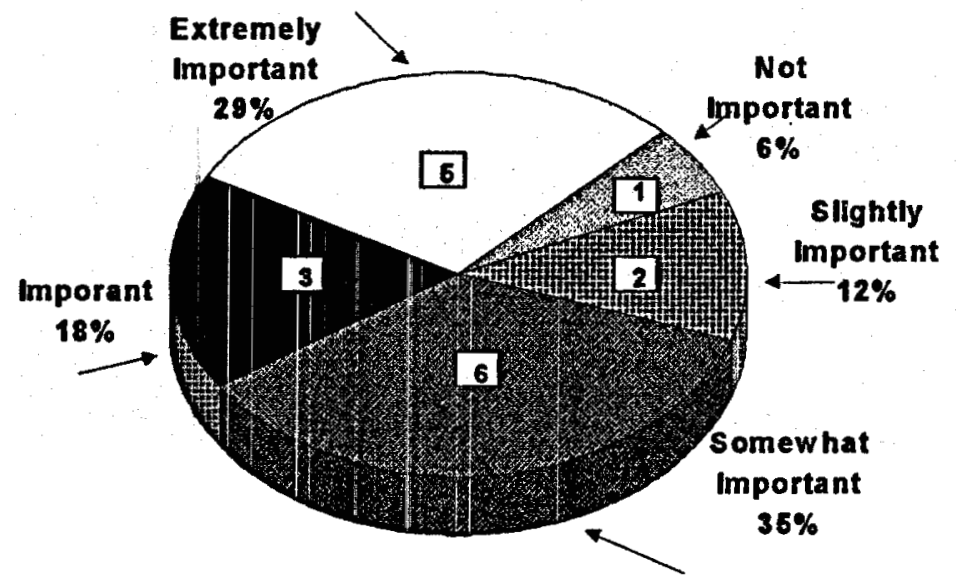


Participants were asked about the coverage of topics. Question \#9 of the questionnaire asks "Should the summer program be less broad (cover fewer topics) and come to greater closure on each topic covered?" Chart 14 below presents their responses. 8 (47.1\%) participants felt the program coverage was about right, $6(35.2 \%)$ participants felt there should be more closure on each topic, while only $3(\mathbf{1 7 . 6 \% )}$ participants felt there should be less topics covered and more coverage on each topic.

\section{Chart 14.}

\section{Scope of Program \\ Should program be less broad?}

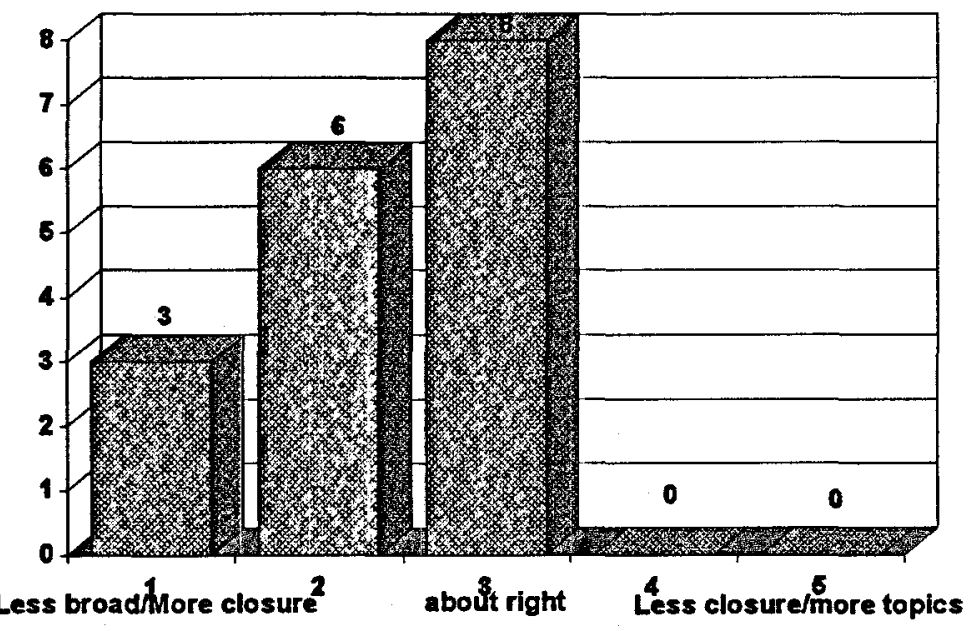

Question 7 on the survey asked about the effectiveness of the program in forming a supportive network of colleagues for participants to lean on for future development. Chart 15 . below presents their responses. Responses were extremely positive with $100 \%$ of the participants feeling that the program was effective or highly effective in establishing the professional network.

\section{Chart 15.}

Networking Effectiveness 1997 JPL/STEP Institute

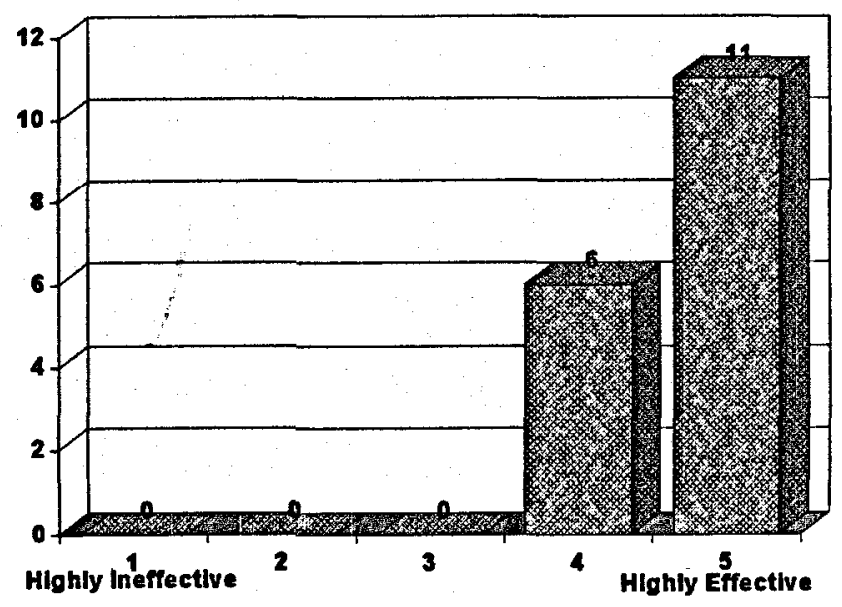


The networking steps taken (requiring EMAIL accounts, Internet access, and a computer) were highly effective compared with last year. Over 90 group messages were circulated via lists among the participants. The social activities also build a sense of team spirit.

When asked how to improve networking effectiveness (question \#8), here is what some of the participants recommended:

- More time for discussions within groups. My feeling is that I've been talked at more than I'd care for. We have a wide range of expertise and experience from within, more facilitation, less lecture.

- I would like to see use of Chat Rooms on the Web.

- To have follow-ups that will strengthen acquired skills from the STEP Program.

- Extend the program to include participation with other STEP classes past and future.

- Provide time for us to share favorite lessons.

- Give participants more hands-on, for example 1 week video-hyperstudio-studio stacks-other technology. Working together to solve problems creates stronger bonds.

- Join a mutual organization (on technology). Present at schools as a team to fan out.

\section{Highlights of Some Written Responses:}

Participant responses from the evaluation questionnaire's open-ended questions were quite enlightening, and worth reading in their entirety (see Appendix C). Typically, participant comments reflected what we've already observed in the charts above and were positive.

\section{What Students Liked (question \#13):}

Some typical comments were:

- The science speakers were invaluable! Touring the various sites were the absolute strengths!

- Very much enjoyed the chance to meet project scientists. The support and encouragement in developing HTML pages was important to me. The social aspect of the program was great and kept everything enjoyable.

- The great emphasis on the applicability of our new found knowledge. The academic cultural in which each participant must be both creative and hardworking. Each student must find the answer to their questions without being completely spoon feed.

- Exposure to JPLANASA \& technologies that are new to me.

- The new experiences presented me with the most challenges-not only mentally, but I had to stretch. I enjoyed listening to the scientist, but especially those who have multiple careers.

- We were exposed to a terrific range of technologies. I feel much more confident at taking technology back to my classroom!

- This class has definitely taken me out of my comfort zone. It has challenged me to think and I feel it was well worth the time spent. I gained so much knowledge about the use of computers. 
What do you plan to do differently in your teaching and classroom as a result of this workshop? (question \#14):

Some plans participants offered for changing their teaching were:

- I plan to use all of the resources I've picked up along the way. The information about space \& aeronautics in my school is outdated. The books, periodicals, lesson plans will be put to use.

- I plan to use more hands-on activities and more structured assessments.

- I plan to use space/earth science as a center from which all of my science teaching branches off.

- Focus more on projects, less on lecture and books.

- I will teach more space science next year-I feel more confident and inspired.

- I plan to do more project centered activities. I also plan to integrate earth and space science into my curriculum.

- Using technology more!

\section{Final Comments:}

- Keep the program funded.

- I learned a lot, and for the most part really enjoyed myself. I feel much more confident about technology \& space/earth science. Rich, Ken, James \& Simeon were a great team and source of information. Thanks!!!

- I think this was a great program! It help me a lot with the technology aspect of it. Furthermore, I had the chance to meet other Science teachers and learned from them. It's a great medium for exchanging knowledge and for networking. I hope this program will continue on!

- I liked being a part of something this global. So do kids! Their eyes widen I would like to learn a little more about the global impact of technology. Yes, it was touched on (Cassini). Just not enough.

\section{Changes in the Participant Teachers (JPL/STEP Outcomes)}

In this section, we will examine the pre-post changes in the teachers themselves. These changes in attitudes, teaching style, comfort levels, and expectations for their own students can reasonably be attributed to the JPL Teacher Enhancement Program. While there was no control group, it is unlikely that such dramatic changes would have occurred among the teachers during their normal summer vacations.

Chart 16. below pairs approaches to teaching to see where teachers place their emphasis. Many desirable changes occurred: for example, because of the STEP program, more teachers will focus on deeper understanding than facts and formulas. The exact wording of each of 
these items referred to in the charts can be found in Appendix B, question \#5 of the "End of Summer Program" questionnaire.

Chart 16.

\section{Approach to Teaching}

1997 JPL/STEP Institute

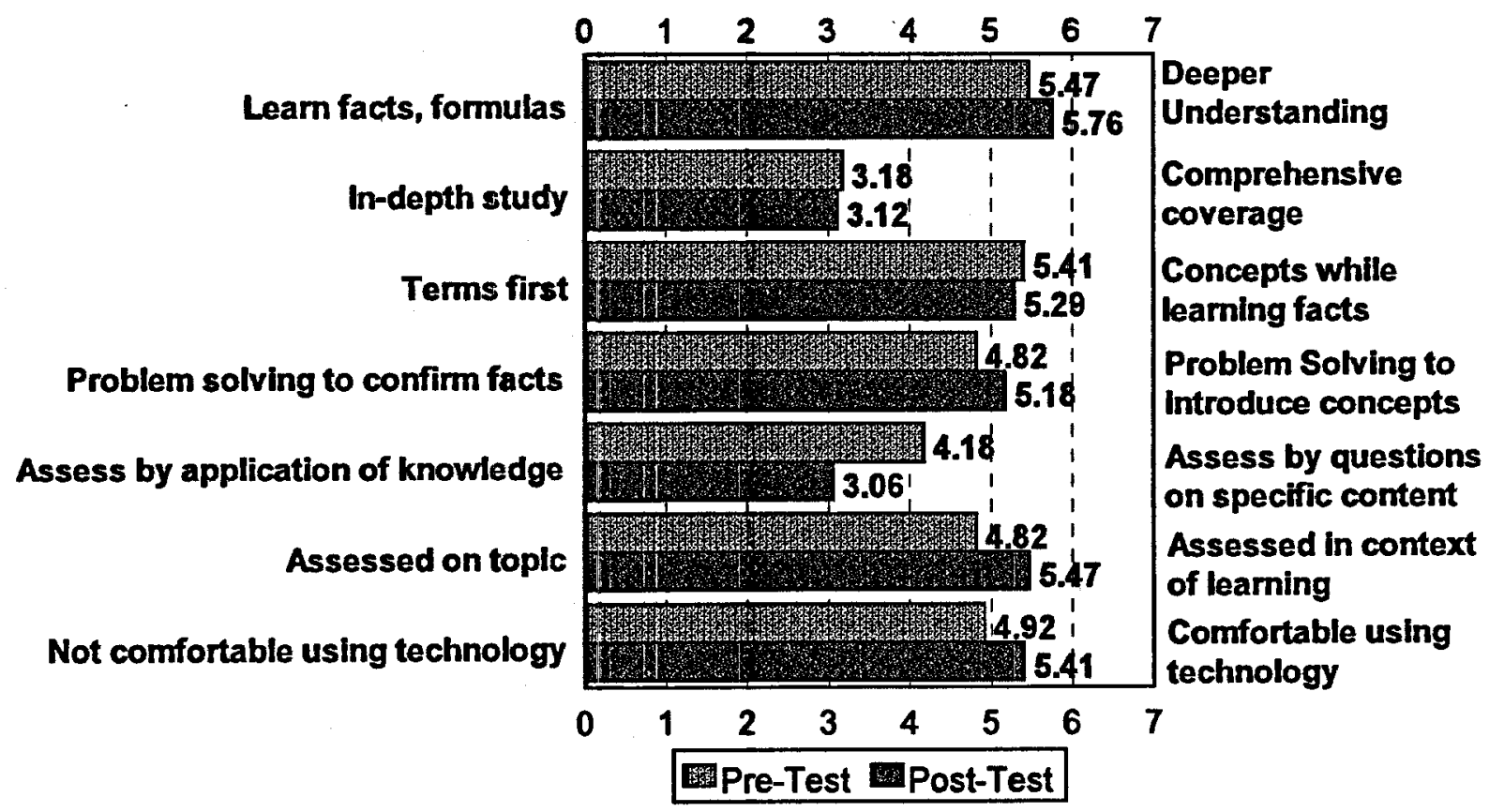

Chart 16. reflects the changes that occurred before and after the JPL/TEP Summer Institute. Some of the more dramatic shifts include less emphasis on science and technology facts - more on gaining deeper understanding, a greater focus on problem solving to confirm facts, and more emphasis on assessment by application of knowledge instead of test questions.

Chart 17 and 18 . below reflects the pre and post program ratings of the personal ability teachers felt they had in teaching science, mathematics, and technical subjects. These charts reflect the changes that occurred before and after the JPL/STEP Summer Institute, and indicate the improvement or change in the participants' self-rated ability or confidence levels (self-efficacy) in different teaching areas. The exact wording of each of these items referred to in the charts can be found in Appendix B, (from question \#6 on the End of Program survey) 


\section{Chart 17.}

\section{Personal Ability Rating}

In Science, Math, and Technology

\begin{tabular}{|l|c|c|c|}
\hline & Pre-Test Mean & Post-Test Mean & Mean Change \\
\hline Knowledge Level & 3.12 & 3.76 & 0.64 \\
\hline Teaching Comfort & 4.35 & 4.18 & -0.17 \\
\hline Class Management & 4.53 & 4.18 & -0.35 \\
\hline Demonstrating & 4.18 & 4.29 & 0.11 \\
\hline Discuss Applications & 3.65 & 3.82 & 0.17 \\
\hline Answer Questions & 4.35 & 4.12 & -0.23 \\
\hline Supervise Projects & 4.18 & 4.41 & 0.23 \\
\hline Telecommunications & 3.38 & 4.12 & 0.74 \\
\hline Multimedia & 4 & 3.65 & -0.35 \\
\hline Cooperative Leaming & 4.59 & 4.71 & 0.12 \\
\hline Computers & 4.41 & 4.71 & 0.3 \\
\hline Designing Lessons & 4.06 & 3.94 & 0.12 \\
\hline Assessment & 3.82 & 4.12 & 0.3 \\
\hline Constructivist Approach & 4 & 4.12 & 0.12 \\
\hline
\end{tabular}

Note: Scale ranges from 1 (lowest) to 5 (highest)

Chart 18.

\section{Change in Self-Rated Ability}

In Teaching Science, Math, \& Technology

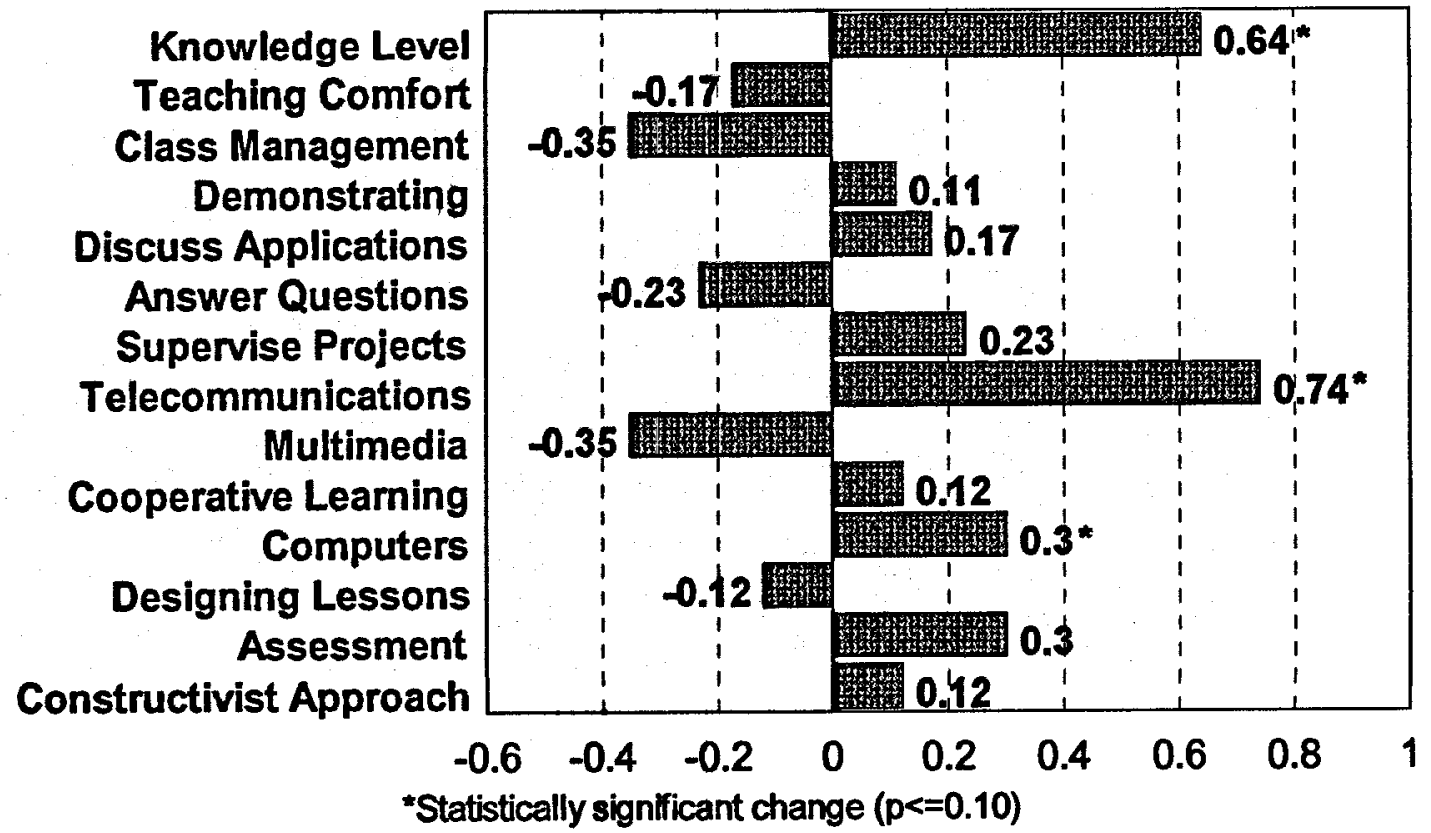


From these charts, we see that because of the workshop participants were humbled in their knowledge about classroom management, their ability to answer science questions, and their ability to design lessons (for active learning). However, in several important areas, the growth in the teachers confidence levels improved significantly. Their confidence or self-efficacy in the areas of knowledge level, using telecommunications, and using computers had improved at a statistically significant level.

In fact, a composite score of the pre and post combined ratings on the participants' comfort and confidence levels in these areas of teaching science was calculated (from items in question \#6) and change or overall improvement was positive. Chart 20 below indicates this change.

\section{Chart 20.}

\section{Science Teaching Confidence Scale}

Pre and Post Workshop Comparisons

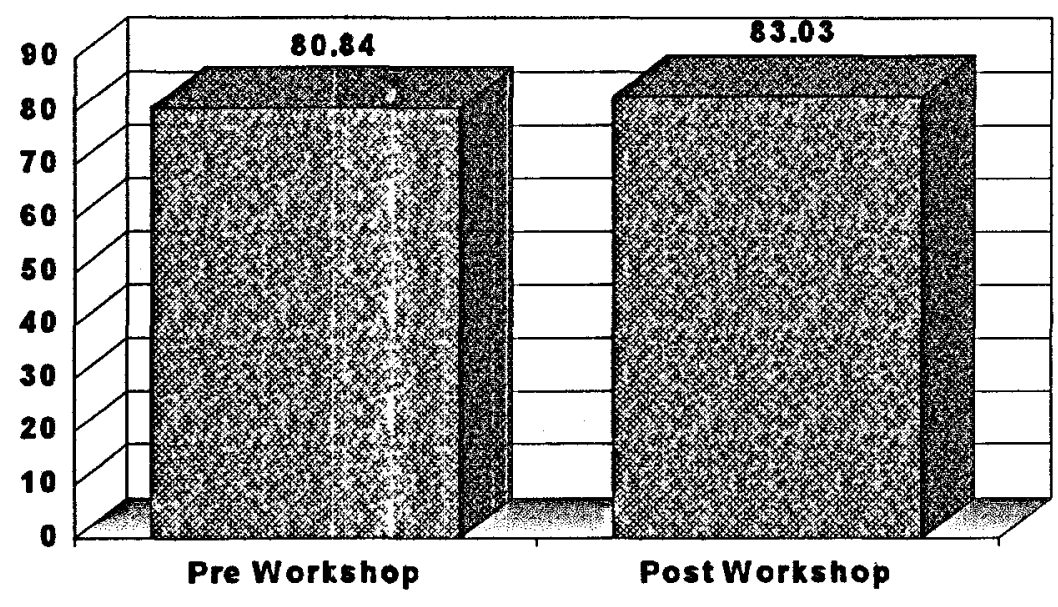

Note: scores based on a 0-100 scale.

\section{Follow-up Activities}

Two things are important to mention because they are innovative and likely to insure the success of follow-up activities. First, an expectation was built into the program that participating teachers would attend an additional days worth of follow-up activities. The incentive is that the participating teachers get college credit for participating in the followup activities. So far, at least eight additional follow-up dates have been scheduled. It might make sense to consider scheduling, on a volunteer basis, some of the follow-up activities at the participants schools so that there can be continued sharing.

Another supplemental evaluation and report is planned to examine the effectiveness of the follow-up activities, observe some of the teachers at work in their classrooms, and compare some longitudinal changes and developments in the history of the STEP program at JPL. 


\section{Appendices}

Appendix A - 1997 JPL Summer Teacher Enhancement Program Schedules

Appendix B - Questionnaires: "Pre Program" and "End of Program"

Appendix C - Written Responses: Open Ended Question Answers and Comments 


\section{Appendix A}

1997 JPL Summer Teacher Enhancement Program Schedule 
199 ISUMMER TEACHER ENHANCEMENT PROGRAM (STEP) PROGRAM SCHEDULE

\begin{tabular}{|c|c|c|c|c|}
\hline $\begin{array}{c}\text { Monday } \\
9: 00-3: 30\end{array}$ & $\begin{array}{c}\text { Tuesday } \\
9: 00-3: 30\end{array}$ & $\begin{array}{l}\text { Wednesday } \\
9: 00-3: 30\end{array}$ & $\begin{array}{l}\text { Thursday } \\
9.00-3: 30\end{array}$ & $\begin{array}{c}\text { Friday } \\
9: 00-12: 00\end{array}$ \\
\hline $\begin{array}{l}\text { Meet at ERC } \\
\text { 1. Introductions } \\
\text { 2. Program Overview \& } \\
\text { Expectations } \\
\text { 3. Warm-up } \\
\text { LUNCH at Baridey's } \\
\text { (11:30 790-2348) } \\
\text { 4. JPL Tour } \\
\text { 5. ERC visit }\end{array}$ & $\begin{array}{l}\text { DRING JPL BADGE } \\
\text { 1. Journals \& webs } \\
\text { 2. Internet NASA } \\
\text { resources on-line } \\
\text { 3. Email } \\
\text { LUNCH at JPL Cafeteria } \\
\text { 4. Adrieanna Ocampo-- } \\
\text { Galileo and Asteroids } \\
\text { 5. Plusses and wishes } \\
\text { HW: Read Guide to Solar } \\
\text { System }\end{array}$ & $\begin{array}{l}\text { MEET at ERC } \\
\text { 1. Randii Wessen - JPL } \\
\text { History } \\
\text { 2. Rich Alvidrez: } \\
\text { Professional Dialogue } \\
\text { 3. LUNCH BY } \\
\text { COMMIITEE } \\
\text { 2. Bubbles } \\
\text { HW: Mugt have ISP by } \\
\text { today }\end{array}$ & $\begin{array}{l}\text { MEET at ERC } \\
\text { 1. Richard Shope- Ice and } 10 \\
\text { Pire } \\
\text { 2. Planet in a box } \\
\text { BAG LUNCH IN PARK } \\
\text { 3. Bubbles } \\
\text { HW: Send first email re } \\
\text { what you want to do as } \\
\text { project. CCMe }\end{array}$ & $\begin{array}{l}\text { MEET at ERC } \\
\text { 1. Sply 11 } \\
\text { Exploration; Dr. Wayne } \\
\text { Lee } \\
\text { 2. Review Journals } \\
\text { 4. Reflections } \\
\text { 5. Program Planning } \\
\text { Committee Meets w/Ken } \\
\text { \& Rich } \\
\text { HW: Be prepared to talk } \\
\text { about standards and } \\
\text { Benchmarks on Mon. }\end{array}$ \\
\hline $\begin{array}{l}\text { Meet at CSLA } \\
\text { 1. David Seidel on Origins } \\
\text { 2. Search Engines and the } \\
\text { Internet } \\
\text { LUNCH } \\
\text { 3. Benchmarks, Standards } \\
\text { HW: Be Prepared to } \\
\text { discuss the Ed. Leadership } \\
\text { Magazine }\end{array}$ & $\begin{array}{l}\text { Meet at CSLA } \\
\text { 1. Dr. Fernado, School of } \\
\text { Education, CSULA } \\
\text { 2. Multiple Intellegence } \\
\text { Quiz } \\
\text { 3. TIP homepage } \\
\text { LUNCH } \\
\text { 3. Hyperstudio }\end{array}$ & $\begin{array}{l}\text { Meet at CSLA } \\
\text { 1. Educational Assessment, } \\
\text { Dr. Anne Hafner, School of } \\
\text { Education, CSULA } \\
\text { 2. Quicktake camera, } \\
\text { scanners } \\
\text { LUNCH by committee } \\
\text { 3. Homepage Authoring } \\
\text { HW: Must have a group } \\
\text { together for Technology } \\
\text { Project, email me with } \\
\text { results }\end{array}$ & $\begin{array}{l}\text { Meet at JPL Welcome } \\
\text { Center } \\
\text { 1. 9:00-11:00 Tools \& } \\
\text { Processes of Science, Dr. } \\
\text { Fred Shair, Educ Affairs } \\
\text { Office } \\
\text { 2. MESA - engineering } \\
\text { activities } \\
\text { Lunch } \\
\text { 3. How science is done- } \\
\text { Bruce Payne } \\
\text { 4. Make Rockets }\end{array}$ & $\begin{array}{l}\text { Meet at CSLA } \\
\text { 1. Desktop Publishing-- } \\
\text { James Wiebe } \\
\text { 2. Program Planning } \\
\text { Committee Meeting } \\
\text { HW: Be prepared to } \\
\text { discuss ACOr Book }\end{array}$ \\
\hline
\end{tabular}




\begin{tabular}{|c|c|c|c|c|}
\hline PROGRAM RECESS & PROGRAM RECESS & $\begin{array}{l}\text { MEET at ERC } \\
\text { 1. Cassini" } \\
\text { Dr. Ellis Miner } \\
\text { Program Review } \\
\text { 2. Using technology in } \\
\text { Education } \\
\text { LUNCH by Committee } \\
\text { 3. Video in Classroom } \\
\text { HW: Have groups ready for } \\
\text { Unit of Practice, email me }\end{array}$ & $\begin{array}{l}\text { Meet at ERC } \\
\text { 1. Astronomy Day } \\
\text { 2. Steve Edberg } \\
\text { 3. Technology Issues in the } \\
\text { Classroom -- a discussion } \\
\text { (Ken) } \\
\text { LUNCH } \\
\text { 4. Mt. Wilson }\end{array}$ & $\begin{array}{l}\text { 1. Rocket Lauching } \\
\text { 2. Speadsheets } \\
\text { 3. Program Planning } \\
\text { committee Meeting }\end{array}$ \\
\hline $\begin{array}{l}\text { Monday } \\
9: 00-3: 30\end{array}$ & $\begin{array}{c}\text { Tuesday } \\
9: 00-3: 30\end{array}$ & $\begin{array}{c}\text { Wednesday } \\
9: 00-3: 30\end{array}$ & $\begin{array}{l}\text { Thursday } \\
9: 00-3: 30\end{array}$ & $\begin{array}{cc}\text { Friday } \\
\quad 9: 00-3: 30 \\
\end{array}$ \\
\hline $\begin{array}{l}\text { MEET Cal State } \\
\text { Dominques Hills } \\
\text { 1. Challenger Center } \\
\text { Video Projects (Ken) } \\
\text { LUNCH } \\
\text { 2. Start work on } \\
\text { Technology project }\end{array}$ & $\begin{array}{l}\text { BRING JPL BADGE - } \\
\text { MEET AT JPL at 8:30 am } \\
\text { 1.Shadow day at JPL } \\
\text { 2.3. JPL Tour } \\
\text { LUNCH } \\
\text { 4.1:30 - 3:30 TOPEX CD- } \\
\text { ROM and activities } \\
\text { (Annette DeCharon } \\
\text { SIR-C Setup }\end{array}$ & $\begin{array}{l}\text { 1. Present project } \\
\text { ideas/Critical Friends } \\
\text { Review } \\
\text { LUNCH } \\
\text { 2. Image Processing (Ben } \\
\text { Seaberry) }\end{array}$ & $\begin{array}{l}\text { 1.Spacebome Imaging } \\
\text { Radar (SIR-C) Education } \\
\text { Program, 9:00-12:00 } \\
\text { LUNCH } \\
\text { 2. Distance Leaming } \\
\text { Workshop (TEAMS), Judi } \\
\text { Snyder-Gordon, Los Angeles } \\
\text { County Office of Education }\end{array}$ & $\begin{array}{l}\text { 1. Minigrant RFP (Rich) } \\
\text { 2. Pollowup Survey } \\
\text { emalled } \\
\text { 3. Present project } \\
\text { ideas/Critical Friends } \\
\text { Review }\end{array}$ \\
\hline $\begin{array}{l}\text { 1. Pollowup Survey results } \\
\text { \& Schedule } \\
\text { 2. Summer evaluations } \\
\text { (Prof. Slovacek) } \\
\text { LUNCH } \\
\text { 3. Design School In-8ervice } \\
\text { Plan }\end{array}$ & $\begin{array}{l}\text { Commencement Luncheon } \\
\text { at Caltech Faculty Club, } \\
\text { (Athenaeum) Card Room } \\
11: 30-1: 30\end{array}$ & 7 & & \\
\hline
\end{tabular}




\section{Appendix B}

\section{Questionnaires: "Pre Program" and "End of Program"}




\section{JPL Summer Teacher Enhancement Program Pre Program Questionnaire (1997-98)}

\section{Background}

Last four digits of your social security number

Today's Date

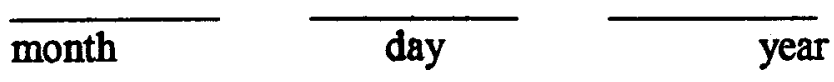

1. Gender (Circle one.) M F

2. What grade level(s) do you currently teach? (Circle all that apply.)
Middle or Junior High School
$\begin{array}{lllll}5 & 6 & 7 & 8 & 9\end{array}$

3a. How many years have you taught the following?

(Fill in the blanks below)

Science

Mathematics

Technology years years years 3b. What do you currently teach? (Check all that apply)

Science Mathematics Technology

\section{Teaching Philosophy and Practice}

4. Indicate to what degree you feel each of the following is an important objective in teaching science, mathematics, or technology. Use the scale below and place the appropriate number in the space provided at the left of each letter.

\begin{tabular}{|c|c|c|c|c|}
\hline $\begin{array}{c}\text { Not } \\
\text { Important }\end{array}$ & $\begin{array}{l}\text { Slightly } \\
\text { Important }\end{array}$ & $\begin{array}{l}\text { Somewhat } \\
\text { Important }\end{array}$ & Important & $\begin{array}{c}\text { Extremely } \\
\text { Important }\end{array}$ \\
\hline 7 & 7 & 3 & 4 & 5 \\
\hline
\end{tabular}

a. Focus on sound pedagogy in teaching.

b. Know and incorporate State Science Framework and National Science Education Standards in teaching.

c. Build curriculum around multiple intelligence theory.

d. Use plenty of hands-on activities.

e. Use authentic assessment in evaluating students' works.

f. Develop new programs and resources to promote new learning (through grant proposal writing and by finding quality science/math/technology programs.) 


\section{Not Slightly Somewhat Extremely \\ $\frac{\text { Important }}{1} \frac{\text { Important }}{2} \cdot \frac{\text { Important }}{3} \frac{\text { Important }}{4} \quad \frac{\text { Important }}{5}$}

g. Focus on increasing students' interest in science/mathematics/technology.

h. Develop and increase in students, a positive attitude about learning.

i. Prepare students for further study in science/mathematics/technology.

j. Increase students' knowledge of important science/mathematics/technology facts.

k. Develop students' skills in scientific inquiry, techniques, processes and problem-solving.

1. Increase students' awareness and perceived importance of science/mathematics/technology in their daily lives.

m. Increase students' awareness of and the desirability of careers in science/math/technology.

n. Integrate teaching and learning of science/mathematics/technology with other subjects.

o. Develop students' skills in telecommunications (Web) and authoring multimedia projects.

p. Develop students' understanding of science/mathematics/technology principles.

q. Develop students' skills in working together (cooperatively/collaboratively).

r. Know the processes and tools of science

s. Become a school leader in showing other teachers new discoveries and learning approaches.

t. Design project-centered or based units of study.

u. Know diverse learning styles among students and be able to tailor instructional practices accordingly.

v. Continue with my professional development as a teacher through courses and workshops.

w. Expand my knowledge and use of technology in my classroom.

x. Design and develop my own curriculum and lessons.

y. Conduct student-centered modes of instruction.

z. Other important goal (please specify) 
4b. For the items above, select and rank the top four (4) in order of importance. (Write the letters in the spaces provided):

most important

2nd most important

3rd most important

4th most important

5. Below are seven pairs of statements. Each pair represents opposite ends of a continuum in approaches to teaching. After reading a pair of statements circle a position on the scale between the statements indicating where you would place your approach (e.g., toward one end, the other, or somewhere in between). Answer for the subject you spend the most time teaching (science, mathematics, or technology).

Pair \#1

A. My primary goals is to help $\begin{array}{llllllll}1 & 2 & 3 & 4 & 5 & 6 & 7 & \text { B. My primary goal is to help }\end{array}$ students learn important facts and formulas and to master key science/mathematics/ technology skills. students achieve a deeper understanding of key science/mathematics/ technology concepts and principles

Pair \#2

A. In my science/mathematics/

$\begin{array}{llllllll}1 & 2 & 3 & 4 & 5 & 6 & 7 & \text { B. In my science/mathematics }\end{array}$ technology course, I aim for intechnology course, I aim for depth study of selected topics and issues even if it means sacrificing coverage. comprehensive coverage even if it means sacrificing in-depth study.

Pair \#3

$\begin{array}{lllllllll}\text { A. My students generally learn } & 1 & 2 & 3 & 4 & 5 & 6 & 7 & \text { B. My students generally learn }\end{array}$ basic scientific terms and formulas before learning underlying concepts and principles. basic scientific terms and formulas while learning underlying concepts and principles.

Pair \#4

A. In my science/mathematics/ $1 \begin{array}{llllllll}1 & 2 & 3 & 4 & 5 & 6 & 7 & \text { B. In my }\end{array}$ technology class, laboratory, investigations, and problem solving are used to confirm previously-learned concepts. science/mathematics/technology class, laboratory investigations, and problem solving are used to introduce and explore concepts. 
Pair \#5
A. I primarily assess my students' learning based on their ability to apply their
$\begin{array}{llllllll}1 & 2 & 3 & 4 & 5 & 6 & 7 & \end{array}$. B. I primarily assess my students' learning based on their ability to answer questions about specific knowledge to new situations. content and processes covered.

Pair \#6
A. I feel that students should
$\begin{array}{llllllll}1 & 2 & 3 & 4 & 5 & 6 & 7\end{array}$
B. I feel that students should be be assessed directly from the topic emphasized in the assessed in context of their learning.

curriculum.

\section{Pair \#7}
A. I do not feel comfortable using technology in my
B. I feel very comfortable using technology in my classroom. classroom - I need more training.

6. Indicate the degree to which you agree or disagree with each of the following statements using the scale below.

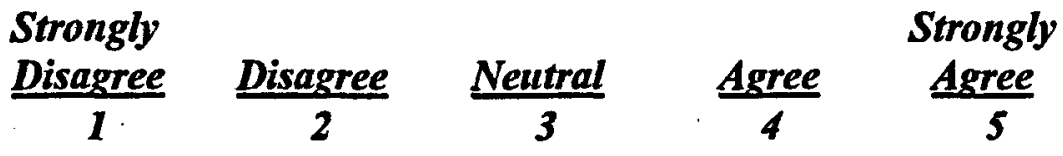

a. I am not comfortable with my current level of science/mathematics/technology knowledge.

b. I feel comfortable teaching science/mathematics/technology.

c. I am not comfortable managing a class of students who are doing hands-on activities.

d. I feel comfortable demonstrating science, mathematics/technology principles to my students.

e. I am still not fully confident in my ability to discuss science/mathematics/technology applications with my students.

f. I feel confident in my ability to help my students answer their own questions.

g. I feel confident in my ability to supervise my students' research projects and experiments.

h. I am not comfortable using telecommunications (WWW) in my school or classroom.

i. I am not comfortable using multimedia applications in my classroom.

j. I feel comfortable having students work cooperatively in projects. 


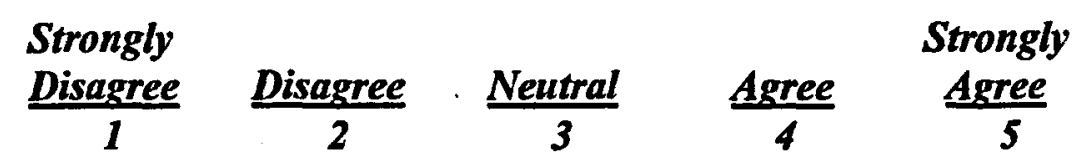

k. I am very comfortable with computers in my class being used as a tool.

1. I feel comfortable designing lessons for learners of all kinds.

m. I feel comfortable assessing students' work using technology in place of standard paper and pencil tests.

n. I feel comfortable using a constructivist approach to teaching science/math/technology.

7. Which of the following school resource committees have you served on or do you currently serve on? (Check all that apply)

Currently Previously

Serve $\quad \underline{\text { Served }}$

$-\quad-\quad \begin{aligned} & \text { a. School Improvement Committee } \\ & \text { b. Local School Leadership (Site Based Management) Council } \\ & \text { c. Technology Planning Committee } \\ & \text { d. LEARN Committee }\end{aligned}$
$\begin{aligned} & \text { e. Annenberg Proposal or project (LAAMP) Committee } \\ & \text { f. Los Angeles Educational Partners (LAEP) }\end{aligned}$

8. What specifically do you hope to gain from this program to improve your teaching? Use the back of this page if necessary. 


\section{JPL Summer Teacher Enhancement Program \\ End of Summer Program Questionnaire (1997)}

\section{Background}

1. Last four digits of your social security number

2. Today's Date

month

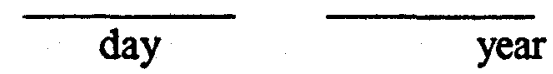

Indicate how you feel each by placing the appropriate number in the space provided at the left of the question.

3. How important is prior computer experience for future STEP participants?

$\begin{array}{lllllll}\text { Not at all important } & 1 & 2 & 3 & 4 & 5 & \text { Very important }\end{array}$

\section{Teaching Philosophy and Practice}

4. Indicate to what degree you feel each of the following is an important objective in teaching science, mathematics, or technology. Use the scale below and place the appropriate number in the space provided at the left of each letter.

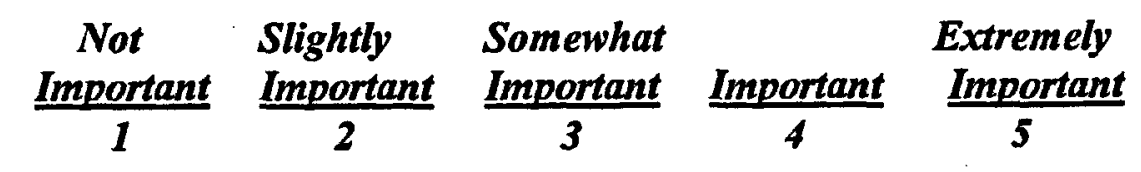

a. Focus on sound pedagogy in teaching.

b. Know and incorporate State Science Framework and National Science Education Standards in teaching.

c. Build curriculum around multiple intelligence theory.

d. Use plenty of hands-on activities.

e. Use authentic assessment in evaluating students' works.

f. Develop new programs and resources to promote new learning (through grant proposal writing and by finding quality science/math/technology programs.) 


\section{Not Slightly Somewhat Extremely \\ Important Important Important Important Important 1 2 3

g. Focus on increasing students' interest in science/mathematics/technology.

h. Develop and increase in students, a positive attitude about learning.

i. Prepare students for further study in science/mathematics/technology.

j. Increase students' knowledge of important science/mathematics/technology facts.

k. Develop students' skills in scientific inquiry, techniques, processes and problem-solving.

1. Increase students' awareness and perceived importance of science/mathematics/technology in their daily lives.

m. Increase students' awareness of and the desirability of careers in science/math/technology.

n. Integrate teaching and learning of science/mathematics/technology with other subjects.

o. Develop students' skills in telecommunications (Web) and authoring multimedia projects.

p. Develop students' understanding of science/mathematics/technology principles.

q. Develop students' skills in working together (cooperatively/collaboratively).

r. Know the processes and tools of science

s. Become a school leader in showing other teachers new discoveries and learning approaches.

t. Design project-centered or based units of study.

u. Know diverse learning styles among students and be able to tailor instructional practices accordingly.

v. Continue with my professional development as a teacher through courses and workshops.

w. Expand my knowledge and use of technology in my classroom.

x. Design and develop my own curriculum and lessons.

y. Conduct student-centered modes of instruction.

z. Other important goal (please specify) 
4b. For the items above, select and rank the top four (4) in order of importance. (Write the letters in the spaces provided):

most important

2nd most important

3 rd most important

4th most important

5. Below are seven pairs of statements. Each pair represents opposite ends of a continuum in approaches to teaching. After reading a pair of statements circle a position on the scale between the statements indicating where you would place your approach (e.g., toward one end, the other, or somewhere in between). Answer for the subject you spend the most time teaching (science, mathematics, or technology).

Pair \#1
A. My primary goals is to help
$\begin{array}{lllllll}1 & 2 & 3 & 4 & 5 & 6 & 7\end{array}$ students learn important facts and formulas and to master key science/mathematics/ technology skills.
B. My primary goal is to help students achieve a deeper understanding of key science/mathematics/ technology concepts and principles

Pair \#2
A. In my science/mathematics/
B. In my science/mathematics technology course, I aim for technology course, I aim for in comprehensive coverage even if it depth study of selected topics means sacrificing in-depth study. sacrificing coverage.

Pair \#3
A. My students generally learn
$\begin{array}{lllllll}1 & 2 & 3 & 4 & 5 & 6 & 7\end{array}$
B. My students generally learn basic scientific terms and formulas before learning underlying concepts and basic scientific terms and formulas while learning underlying concepts and principles. principles.

Pair \#4
A. In my science/mathematics/
1234 technology class, laboratory, investigations, and problem solving are used to confirm previously-learned concepts.

B. In my
science/mathematics/technology
class, laboratory investigations,
and problem solving are used to
introduce and explore concepts.


Pair \#5
A. I primarily assess my students' learning based on

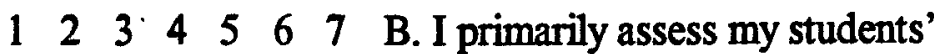 learning based on their ability to their ability to apply their answer questions about specific knowledge to new situations. content and processes covered.

Pair \#6
A. I feel that students should
$\begin{array}{lllllll}1 & 2 & 3 & 4 & 5 & 6 & 7\end{array}$
B. I feel that students should be assessed in context of their be assessed directly from the topic emphasized in the learning.

curriculum.

\section{Pair \#7}
A. I do not feel comfortable using technology in my
$\begin{array}{lllllll}1 & 2 & 3 & 4 & 5 & 6 & 7\end{array}$
B. I feel very comfortable using classroom - I need more technology in my classroom. training.

6. Indicate the degree to which you agree or disagree with each of the following statements using the scale below.

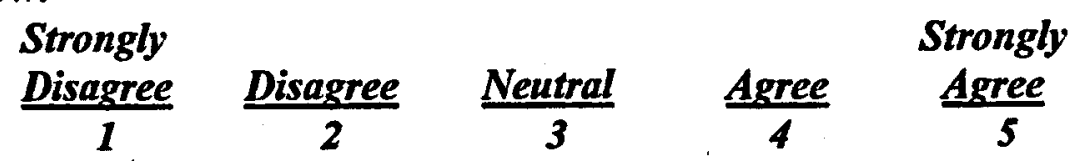

a. I am not comfortable with my current level of science/mathematics/technology knowledge.

b. I feel comfortable teaching science/mathematics/technology.

c. I am not comfortable managing a class of students who are doing hands-on activities.

d. I feel comfortable demonstrating science, mathematics/technology principles to my students.

e. I am still not fully confident in my ability to discuss science/mathematics/technology applications with my students.

f. I feel confident in my ability to help my students answer their own questions.

g. I feel confident in my ability to supervise my students' research projects and experiments.

h. I am not comfortable using telecommunications (WWW) in my school or classroom.

i. I am not comfortable using multimedia applications in my classroom.

j. I feel comfortable having students work cooperatively in projects. 


\section{Strongly \\ $\frac{\text { Disagree }}{1} \quad \frac{\text { Disagree }}{2} \quad \frac{\text { Neutral }}{3} \quad \frac{\text { Agree }}{4} \quad \frac{\text { Agree }}{5}$}

k. I am very comfortable with computers in my class being used as a tool.

1. I feel comfortable designing lessons for learners of all kinds.

m. I feel comfortable assessing students' work using technology in place of standard paper and pencil tests.

n. I feel comfortable using a constructivist approach to teaching science/math/technology.

\section{General Questions about the program}

7. How effective have we been in forming a supportive network of colleagues for you to lean on for future professional development?

Highly Ineffective $1 \quad 2 \quad 3 \quad 3 \quad 4 \quad 5$ Highly Effective

8. What could we do differently to build an even stronger network of colleagues?

9. Should the summer program be less broad (cover fewer topics) and come to greater closure on each topic covered?

Less broad \&

More closure

1

$\underset{3}{\text { about right }}$

Cover

more topics

4.5

10. How does STEP compare with other in-service professional development programs for science/math teachers in which you've participated?

Much worse

1

Average

23

$3 \quad 4$

Much better The Best

6

11. Would you recommend this program to your fellow teachers?
1. Yes, definitely
2. Maybe
3. No 
12. Using the scale below please rank each of the different aspects of the program by placing the appropriate number in the space provided.

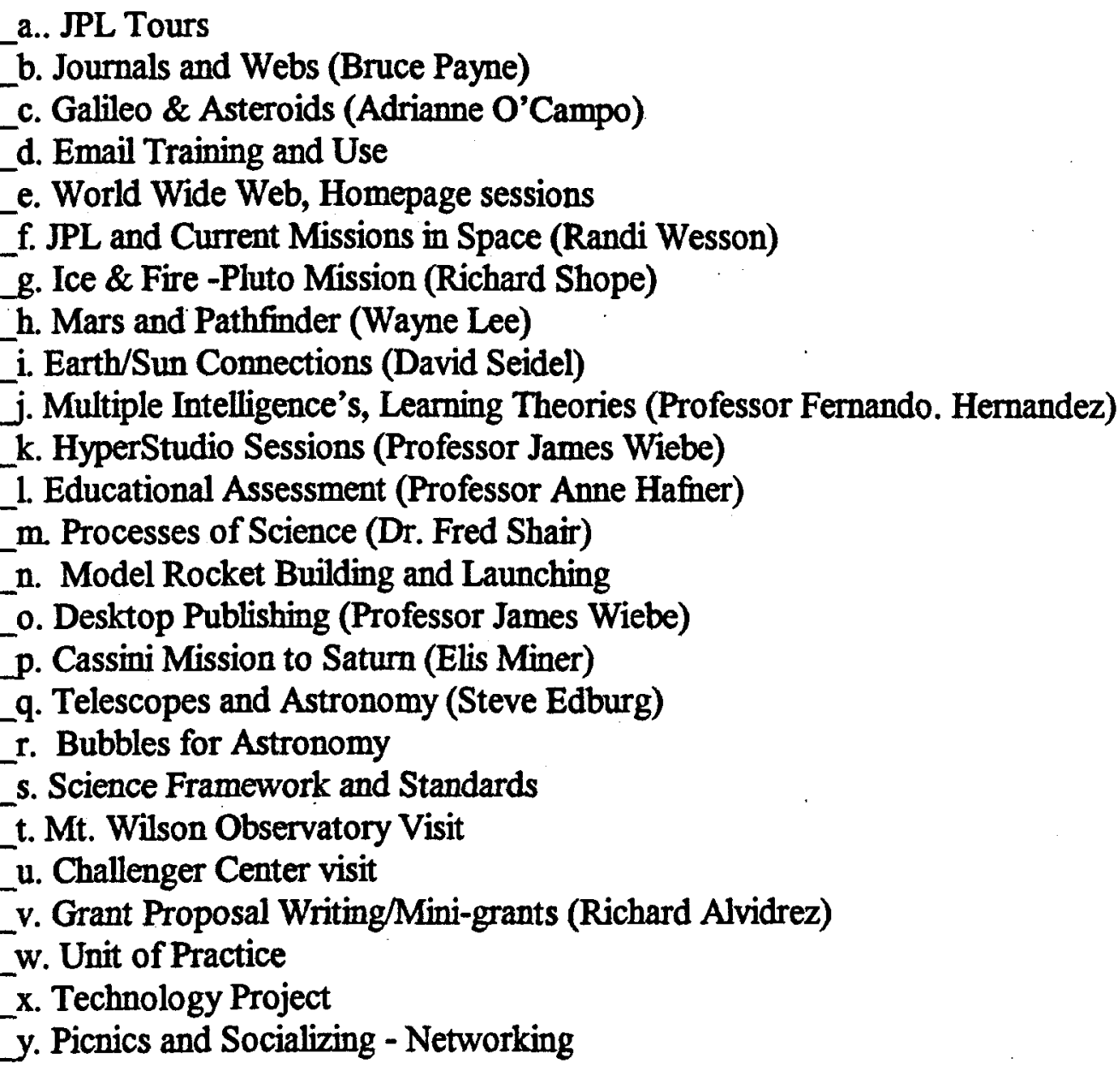

13. What did you like best about the JPL Summer Teacher Enhancement Program? 
14. What did you like least about the Program? (if you could change one thing about the program, what would it be?)

15. What do you plan do differently in your teaching and classroom as a result of this workshop? Be Specific.

16. Are there any final comments, suggestions, or thoughts you would like to share on the program? (use the other side if you need more space)

Thanks for sharing your thoughts.

page 7 


\section{Appendix C \\ Written Responses: \\ Open Ended Question Answers and Comments}




\section{JPL Summer Teacher Enhancement Program \\ End of Summer Program Questionnaire (1997)}

8. What could we do differently to build an even stronger network of colleagues?

3. More time for discussions within groups. My feeling is that I've been talked at more than I'd care for. We have a wide range of expertise and experience from within, more facilitation, less lecture.

4. I would like to see use of Chat Rooms on the Web.

5. To have follow-ups that will strengthen acquired skills from the STEP Program.

7. Extend the program to include participation with other STEP classes past and future.

9. Provide time for us to share favorite lessons.

11. I think you've done a great job already!

15. Give participants more hands, for example 1 week video-hyperstudio-studio stacks- other technology-working together to solve problems creates stronger bonds.

16. Keep up the good work, but make sure you give hand-outs on directions dealing with how to make or use some of the tech. assignment.

17. Dr. Wiebe was of great help, could have used more hands on help form other instructors.

18. Join a mutual organization (technology). Present at school's as a team (2) fan out.

19. Not much, communication avenues are well established.

\section{What did you like best about the JPL Summer Teacher Enhancement} Program?

3. The science speakers were invaluable! Touring the various sites were the absolute strengths!

4. Very much enjoyed the chance to meet project scientists. The support and encouragement in developing HTML pages was important to me. The social aspect of the program was great and kept everything enjoyable. 
5. The great emphasis on the applicability of our new found knowledge. The academic cultural in which each participant must be both creative and hardworking. Each student must find the answer to their questions without being completely spoon feed:

6. Exposure to JPLANASA \& technologies that are new to me.

7. We got paid. This allowed me to do this rather than having to work. Thank you. Quality speakers, general applicability of the content covered and skills applied.

8. E-mail, speakers, going to JPL.

9. I liked listening to the speakers in the mornings-especially Wayne Lee and Bruce Payne. The project scientists and engineers were fascinating. I like their expertise and enthusiasm.

10. Meeting new people \& hearing the scientists from JPL.

11. All of the above!!!

12. Being in an environment where I could learn a lot about space and technology, \& meet so many interesting scientists, and make a lot of new friends.

14. Hearing from the real scientists, Bruce Payne.

15. The new experiences presented me with the most challenges-not only mentally, but I had to stretch. I enjoyed listening to the scientist, but especially those who have multiple careers.

16. The comrade and friendship. A source for getting information and help on the latest information in teaching.

17. Payne, Wiebe, Wayne Lee. Adnanne Ocampo great speakers. Richard Shope - The MANAT Sun Obser. Mt. Wilson. (scientist no docent)

18. I thoroughly enjoyed all visitations. The speakers with slides or video would also receive a high rating. Rocketry was awesome, so was hyperstudio.

19. We were exposed to a terrific range of technologies. I feel much more confident at taking technology back to my classroom! 
20. This class has definitely taken me out of my comfort zone. It has challenged me to think and I feel it was well worth the time spent. I gained so much knowledge about the use of computers.

14. What did you like least about the Program? (if you could change one thing about the program, what would it be?)

3. As I've said previously - more interaction between the steppers is needed. A note - one of the things stressed pedagogically in the program was "teachers as coach or facilitator". More coaching!

\section{The long drive.}

6. This Form! Some disparity between teaching techniques that we are to use \& use \& those that were used for us.

7. Ken needs to use cooperative learning methods to summarize and apply material learned in lectures, rather than continuing to lecture the same thing over again but from his angle. Suggestions-more team summarize, answered questions, and present rather than Ken asking questions and commenting on our answers, let us teach each other.

8. Still have speakers but spend one week on hyperstudio, videos, desktop publishing, WWW/homepages and bookmarks.

9. I would have liked to end with a portfolio of hands-on-experiments about space science.

10. We sat far too long.

11. Shorter lecture and more hands-on activities!

12. These should have been an earlier emphasis on teaching us the technology. It created stress to know we had to do a project but hadn't been shown how to do it until later.

14. Unit of practice - waste of time, can do on my own. Would rather hear from more scientists or teachers who have tech. in progress in their classes like Bruce.

15. If we are expected, as teachers, to be more creative and less lecture basedinstructors who teach teachers should model that behavior.

16. I don't see anything that I like least, however I do recall the multiple intelligent theory presented by on of the guest speakers as being redundent and repetitive. That does not mean that it was bad. 
17. Eliminate, bubbles, Hafner (nice lady, good speaker but didn't need content. Science Framework. Unit of Practice) needed not lesson plans, but practice with computer technology. I could have used more time. Eliminate Hernandez, we already cover that at LAUSD.

18. The two speakers at Cal State didn't capture me or keep my attention like the others (Fernando, Anne).

19. There needs to be a much more focused, thorough handling of daily events and topics. We need to very definitively start and finish our treatment of each area before moving into applications.

20. Not one thing.

15. What do you plan to do differently in your teaching and classroom as a result of this workshop? Be Specific.

3. I plan to use all of the resources I've picked up along the way. The information about space \& aeronautics in my school is outdated. The books, periodicals, lesson plans will be put to use.

5. I plan to use more hands-on activities and more structured assessments.

6. I plan to use space/earth science as a center from which all of my science teaching branches off.

7. Focus more on projects, less on lecture and books.

8. Walk slow, drink alot of water, and don't run!

9. I will teach more space science next year-I feel more confident and inspired.

10. I plan to do more project centered activities. I also plan to integrate earth and space science into my curriculum.

11. Using technology more!

12. Teach a lot more about space and technology. These areas were not my strong points, and I've learned so much here that will give me confidence to bring all these ideas into the classroom.

14. Have students actively experience more science through hands-on techniques and worry less about facts and vocabulary. 
15. I do plan to use a lot of the things I've learned in this class. Multiple Intelligences impressed me and I'll be more aware and observant.

16. Introduce technology program, especially hyperstudio for the visual learning students.

17. With those extra hours we could learn to use more tech. We already know how to make lesson plans. Give us prepared activities! More Tech!

18. I would use the Internet, Web Page Newsletter and Hyperstudio in my classes.

19. Use Technology!!! Make movies, create hyperstudio projects, create home pages!!!

20. I hope to incorporate some of the lessons and ideas I have been given to gradually let go of the control issues that have been a large part of the ways in which I run my class.

16. Are there any final comments, suggestions, or thoughts you would like to share on the program? (use the other side if you need more space)

3. I wonder if there can be sub-groups within STEP as far as technology goes. Some members have a more advanced working knowledge of things technical.

5. Keep the program funded.

6. Excellent program, but I still hate this form.

\section{Go with God!}

9. I don't think the technology project and unit of study project were valuable learning tools.

10. I learned a lot, and for the most part really enjoyed myself. I feel much more confident about technology \& space/earth science. Rich, Ken, James \& Simeon were a great team and source of information. Thanks!!!

11. I think this was a great program! It help me alot with the technology aspect of it. Furthermore, I had the chance to meet other Science teachers and learned from them. It's a great medium for exchanging knowledge and for networking. I hope this program will continue on!

12. Although the STEP program has been especially valuable to me, and I have come away with many new ideas \& teaching moments, it was a lot of work. Not $t$ hat that's bad in itself - it isn't. But it was stressful in the beginning when we kept 
hearing about what we had to do, but weren't getting the training to do it. Put your tech. training earlier in your scheduling so we can be working on our assignments as we go along. I wouldn't have missed a moment of the program but you should try to eliminate the stress for those who don't have much experience in technology. completing the projects (and working on them) was confidence - building and a fantastic experience. I wish we'd been able to do it earlier. Overall - a great program - very valuable. I'm glad I got to participate because it's changed the direction I want my future to go in. I'm going to sign up for the MA in Computer Education. I think all this technology is fascinating! I hope you get refunded - what a shame if no one else gets to experience the program.

15. I came to this program with a full plate-so-0-o I was totally freaked in the first week and the second week. Third \& fourth weeks I was calmer because my plate was less full. However, I do believe strongly that all steppers should experience all of the types of technology assignments. If the program continues to incorporate so much then I would suggest it be experimental. There is a difference in absorbing information you can use and being expected to incorporate that information without enough time or instruction. Consequently I feel technology should be combined with scientific presentations.

16. Keep up the good and perhaps bring in more speakers that can do activities with the teachers to take to their classrooms. Thank you for giving me this opportunity.

18. I liked being a part of something this global. So do kids! Their eyes widen I would like to learn a little more about the global impact of technology. Yes, it was touched on (cassini). Just not enough.

19. It's been a very worthwhile summer. I'm glad I chose to spend my summer here. I strongly suggest, however, that the next facilitator of similar projects approach the group as professional who require an organized, consistent agenda. It was pretty chaotic.

20. It was very intense. Make a workshop for those individuals that have very little knowledge of the computer. 